\title{
Victims or perpetrators: contribution and response of insects to forest diebacks and declines
}

\author{
Aurélien Sallé $^{1} \cdot$ Christophe Bouget ${ }^{2}$
}

Received: 27 July 2020 / Accepted: 7 September 2020 / Published online: 28 October 2020

(C) The Author(s) 2020

\begin{abstract}
- Key message Unprecedented forest declines and diebacks are expected worldwide in response to global change. Insects can trigger or contribute to these disturbances, which can in turn have either beneficial or detrimental retroactive cascading effects on insect communities. However, we are still unsure of the effects that pests will have on these disturbances in the future, and new biodiversity and pest management strategies still need to be put into place. Several recent contributions to Annals of Forest Science address these issues.
\end{abstract}

Forest ecosystems worldwide are currently facing increasing amounts of biotic and abiotic environmental stress, which severely challenges both their acclimation and adaptation capacities (Allen et al. 2010; Carnicer et al. 2011). As a result, extended forest diebacks, or declines, are becoming escalating global phenomena (Allen et al. 2010). The two terms have been used interchangeably (Ciesla and Donaubauer 1994), but it seems that "decline" more generally refers to multifactorial and progressive loss of tree vigor (Sinclair 1967; Manion 1981; Ciesla and Donaubauer 1994), while "dieback" refers to rapid tree mortality, driven by a major biotic or abiotic agent, such as the ash dieback (Pautasso et al. 2013).

Insects are key components of forest biota. From a functional standpoint, they play major roles in several forest ecosystem processes, such as wood decomposition due to the

Handling Editor: Erwin Dreyer

Contributions of the co-authors All co-authors contributed to the text and approved its final version.

This article is part of the Topical Collection on Entomological issues during forest diebacks

Aurélien Sallé

aurelien.salle@univ-orleans.fr

Christophe Bouget

christophe.bouget@inrae.fr

1 Laboratoire de Biologie des Ligneux et des Grandes Cultures, INRAE, Université d'Orléans, 45067 Orléans, France

2 INRAE, UR EFNO, Domaine des Barres, Nogent-sur-Vernisson, France numerous saproxylic species (Grove 2002), and in trophic webs as key prey, predators, and herbivores (Yang and Gratton 2014). In addition to their animal biomass, they also make a major contribution to the tremendous biodiversity found in forests (Stork 2018). Within the frame of global change, forest insect populations are currently undergoing major shifts in their geographical range and population dynamics. In this context, forest insects can act as major drivers of diebacks or as inciting factors of declines (e.g., Thomas et al. 2002; Biedermann et al. 2019). Bark and wood boring species can also take advantage of the weakening of trees and act as contributing factors of declines (Sallé et al. 2014). Both dieback and decline dramatically alter the organization and functioning of forest ecosystems (e.g., Štursová et al. 2014; Hoven et al. 2020), and can consequently have cascading effects on forest insect communities, potentially over large spatial and temporal scales (e.g., Winter et al. 2015). All these situations are illustrated in the topical issue "Entomological issues during forest diebacks" and recent publications in Annals of Forest Science.

Climate change can promote thermophilous species through direct selective effects of warming on developmental and behavioral traits (Bale et al. 2002), and also through direct and indirect effects on forest health (Seidl et al. 2017). Several recent contributions to the journal deal with insects (often Mediterranean species) showing a recent increase in damage levels, or an extension of their geographical range (Bellahirech et al. 2019; Poole et al. 2019; Sánchez-Osorio et al. 2019; Torres-Vila et al. 2019; Sallé et al. 2020).

Ever-increasing import rates and trade volumes foster the introduction and establishment of invasive forest species, 
which can be major drivers of forest diebacks (Roy et al. 2014; Liebhold et al. 2017). On this subject, the paper by Coleman et al. (2019) provides a preliminary susceptibility assessment of two invasive ambrosia beetles, Euwallacea whitfordiodendrus (Schedl) and Euwallacea kuroshio Gomez and Hulcr, for both native and ornamental trees in North America. The paper by Orlova-Bienkowskaja et al. (2020) describes the population of Agrilus planipennis Fairmaire recently introduced in the Moscow area, as well as the insect's westward progression through Europe, and commonly infested host tree species.

Interestingly, most recent contributions to Annals of Forest Science regarding climate change effects on forest pests and invasive species deal with either Buprestidae (OrlovaBienkowskaja et al. 2020; Poole et al. 2019; Torres-Vila et al. 2019; Sallé et al. 2020) or ambrosia beetles (Bellahirech et al. 2019; Coleman et al. 2019). This reflects growing concerns worldwide surrounding these two groups of wood borers. Both groups include several prominent invasive species (e.g., Orlova-Bienkowskaja et al. 2020; Coleman et al. 2019) and also some thermophilous secondary pests, in particular buprestids, which are favored by both direct and indirect impacts of climate change (Bellahirech et al. 2019; Poole et al. 2019; Torres-Vila et al. 2019; Sallé et al. 2020).

The management of these growing issues requires tools to monitor damage distribution and evolution. Torres-Vila et al. (2019) propose a novel method, using Google Street View, to detect and map oak shoot browning at a regional scale. Oak shoot browning is a potential inciting factor of oak decline in the Iberian Peninsula and is caused either by a pathogen, or Coraebus florentinus Herbst. The investigations conducted by Bellahirech et al. (2019) and Sánchez-Osorio et al. (2019) could allow us to identify the stands or trees at risk of colonization by Platypus cylindrus Fabricius and Cerambyx welensii Küster, respectively. The investigation concerning the chemical ecology of $C$. welensii may improve the management of this pest and could, for instance, facilitate the development of efficient lures.

There is accumulating evidence that insect diversity is undergoing a significant decline (e.g., Hallmann et al. 2017; Seibold et al. 2019) and that this trend also affects forest insect communities (Homburg et al. 2019; Seibold et al. 2019). Both forest declines and diebacks are disturbances that may affect some critical resources. However, they also generate biological and/or structural legacies such as snags and logs (Franklin et al. 2002), thereby creating novel colonization opportunities for forest species, and in particular saproxylic species, which depend on dead or weakened trees and associated resources (Grove 2002). This may result in short- or long-lasting biodiversity pulses, depending on the disturbance frequency, spatial extent, and intensity (e.g., Winter et al. 2015; Kozák et al. 2020). In their paper, Sallé et al. (2020) show that an oak decline can have contrasting impacts on canopy-dwelling beetles, depending on their trophic guild. Although it favors saproxylic beetles in general, it may negatively affect some leaf-eating species.

Overall, these papers call for further studies to better predict, monitor, and manage the damage caused by both invasive and increasingly aggressive native pests. A worldwide multidisciplinary research agenda in order to fill lingering knowledge gaps could also focus on comparative studies of (i) large-scale effects of forest dieback/decline in forest landscapes on regional dynamics of insect pests and biodiversity, (ii) long-term or cumulative effects over time of dieback/ decline on pest and biodiversity dynamics, (iii) the potential occurrence of response thresholds for insect diversity metrics or ecosystem functions to a forest dieback gradient (Evans et al. 2017), and (iv) feedback and non-linear interactions between climate-induced declines and other climate-related disturbance processes, such as insect outbreaks. We need to better assess the functional outcomes of the unprecedented level of forest decline expected to affect forests worldwide, and to propose management strategies which include declining areas when planning conservation networks.

Data availability Data sharing is not applicable to this article (no dataset).

\section{Compliance with ethical standards}

Conflict of interest The authors declare that they have no conflict of interest.

Open Access This article is licensed under a Creative Commons Attribution 4.0 International License, which permits use, sharing, adaptation, distribution and reproduction in any medium or format, as long as you give appropriate credit to the original author(s) and the source, provide a link to the Creative Commons licence, and indicate if changes were made. The images or other third party material in this article are included in the article's Creative Commons licence, unless indicated otherwise in a credit line to the material. If material is not included in the article's Creative Commons licence and your intended use is not permitted by statutory regulation or exceeds the permitted use, you will need to obtain permission directly from the copyright holder. To view a copy of this licence, visit http://creativecommons.org/licenses/by/4.0/.

\section{References}

Allen CD, Macalady AK, Chenchouni H, Bachelet D, McDowell N, Vennetier M, Kitzberger T, Rigling A, Breshears DD, Hogg EH, Gonzalez P, Fensham R, Zhang Z, Castro J, Demidova N, Lim J-H, Allard G, Running SW, Semerci A, Cobb N (2010) A global overview of drought and heat-induced tree mortality reveals emerging climate change risks for forests. For Ecol Manag 259:660-684

Bale JS, Masters GJ, Hodkinson ID, Awmack C, Bezemer TM, Brown VK, Butterfield J, Buse A, Coulson JC, Farrar J, Good JEG, Harrington R, Hartley S, Jones TH, Lindroth RL, Press MC, Symrnioudis I, Watt AD, Whittaker JB (2002) Herbivory in global climate change research: direct effects of rising temperature on insect herbivores. Glob Change Biol 8:1-16 
Bellahirech A, Branco M, Catry FX, Bonifácio L, Sousa E, Jamâa MLB (2019) Site-and tree-related factors affecting colonization of cork oaks Quercus suber L. by ambrosia beetles in Tunisia. Ann For Sci 76:45

Biedermann PH, Müller J, Grégoire JC, Gruppe A, Hagge J, Hammerbacher A, Hofstetter R, Kandasamy D, Miroslav K, Kostovcik M, Krokene P, Sallé A, Six D, Turrini T, Vanderpool D, Wingfield M, Bässler C (2019) Bark beetle population dynamics in the Anthropocene: challenges and solutions. Trends Ecol Evol 34: 914-924

Carnicer J, Coll M, Ninyerola M, Pons X, Sanchez G, Penuelas J (2011) Widespread crown condition decline, food web disruption, and amplified tree mortality with increased climate change-type drought. Proc Nat Acad Sci 108:1474-1478

Ciesla W M, Donaubauer E (1994) Decline and dieback of trees and forests: a global overview. FAO Forestry Paper. 120, $90 \mathrm{p}$

Coleman TW, Poloni AL, Chen Y, Thu PQ, Li Q, Sun J, Rabaglia RJ, Man G, Seybold SJ (2019) Hardwood injury and mortality associated with two shot hole borers, Euwallacea spp., in the invaded region of southern California, USA, and the native region of Southeast Asia. Ann For Sci 76:61

Evans PM, Newton AC, Cantarello E, Martin P, Sanderson N, Jones DL, Barsoum N, Cottrell JE, A'Hara SW, Fuller L (2017) Thresholds of biodiversity and ecosystem function in a forest ecosystem undergoing dieback. Sci Rep 7:6775

Franklin JF, Spies TA, Van Pelt R, Carey AB, Thornburgh DA, Berg DR, Lindenmayer DB, Harmon ME, Keeton WS, Shaw DC, Bible K, Chen J (2002) Disturbances and structural development of natural forest ecosystems with silvicultural implications, using Douglas-fir forests as an example. For Ecol Manag 155:399-423

Grove SJ (2002) Saproxylic insect ecology and the sustainable management of forests. Ann Rev Ecol Syst 33:1-23

Hallmann CA, Sorg M, Jongejans E, Siepel H, Hofland N, Schwan H, Stenmans W, Müller A, Sumser H, Hörren T, Goulson D, de Kroon $\mathrm{H}$ (2017) More than 75 percent decline over 27 years in total flying insect biomass in protected areas. PLoS One 12:e185809

Homburg K, Drees C, Boutaud E, Nolte D, Schuett W, Zumstein P, Von Ruschkowski E, Assmann T (2019) Where have all the beetles gone? Long-term study reveals carabid species decline in a nature reserve in Northern Germany. Insect Conserv Diver 12:268-277

Hoven BM, Knight KS, Peters VE, Gorchov DL (2020) Release and suppression: forest layer responses to emerald ash borer (Agrilus planipennis)-caused ash death. Ann For Sci 77:10

Kozák D, Svitok M, Wiezik M, Mikoláš M, Thorn S, Buechling A, Hofmeister J, Matula R, Trotsiuk V, Bace V, Begovic K, Cada V, Dusatko M, Frankovic M, Horak J, Janda P, Kameniar O, Nagel TA, Pettit JL, Pettit JM, Synek M, Wiezikova A, Svoboda M (2020) Historical disturbances determine current taxonomic, functional and phylogenetic diversity of saproxylic beetle communities in temperate primary forests. Ecosystems. https://doi.org/10.1007/s10021020-00502-x

Liebhold AM, Brockerhoff EG, Kalisz S, Nuñez MA, Wardle DA, Wingfield MJ (2017) Biological invasions in forest ecosystems. Biol Invasions 19:3437-3458

Manion PD (1981) Tree disease concepts. Prentice-Hall, Englewood Cliffs

Orlova-Bienkowskaja MJ, Drogvalenko AN, Zabaluev IA, Sazhnev AS, Peregudova EY, Mazurov SG, Komarov EV, Struchaev VV,
Martinov VV, Nikulina TV, Bieńkowski AO (2020) Current range of Agrilus planipennis Fairmaire, an alien pest of ash trees, in European Russia and Ukraine. Ann For Sci 77:1-14

Pautasso M, Aas G, Queloz V, Holdenrieder O (2013) European ash (Fraxinus excelsior) dieback - a conservation biology challenge. Biol Conserv 158:37-49

Poole EM, Ulyshen MD, Horn S, Cram M, Olatinwo R, Fraedrich S (2019) Biology and distribution of Agrilus macer LeConte (Coleoptera: Buprestidae), a species associated with sugarberry (Celtis laevigata Willd.) mortality in the southeastern USA. Ann For Sci 76:7

Roy BA, Alexander HM, Davidson J, Campbell FT, Burdon JJ, Sniezko R, Brasier C (2014) Increasing forest loss worldwide from invasive pests requires new trade regulations. Front Ecol Environ 12:457-465

Sallé A, Nageleisen L-M, Lieutier F (2014) Bark and wood boring insects involved in oak declines in Europe: current knowledge and future prospects in a context of climate change. For Ecol Manag 328:79-93

Sallé A, Parmain G, Nusillard B, Pineau X, Brousse R, Fontaine-Guenel T, Ledet R, Vincent-Barbaroux C, Bouget C (2020) Forest decline differentially affects trophic guilds of canopy-dwelling beetles. Ann For Sci 77:86. https://doi.org/10.1007/s13595-020-00990-w

Sánchez-Osorio I, López-Pantoja G, Tapias R, Pareja-Sánchez E, Domínguez L (2019) Monoterpene emission of Quercus suber L. highly infested by Cerambyx welensii Küster. Ann For Sci 76:98

Seibold S, Gossner MM, Simons NK, Blüthgen N, Müller J, Ambarli D, Ammer C, Bauhus J, Fischer M, Habel JC, Linsenmair KE, Nauss T, Penone C, Prati D, Schall P, Schulze E-D, Vogt J, Wöllauer S, Weisser WW (2019) Arthropod decline in grasslands and forests is associated with landscape-level drivers. Nat 574:671-674

Seidl R, Thom D, Kautz M, Martin-Benito D, Peltoniemi M, Vacchiano G, Wild J, Ascoli D, Petr M, Honkaniemi J, Lexer MJ, Trotsiuk V, Mairota P, Svoboda M, Fabrika M, Nagel TA, Reyer CPO (2017) Forest disturbances under climate change. Nat Clim Chang 7:395-402

Sinclair WA (1967) Decline of hardwoods: possible causes, in: International Shade Tree Conference, pp. 17-32

Stork NE (2018) How many species of insects and other terrestrial arthropods are there on Earth? Annu Rev Entomol 63:31-45

Štursová M, Šnajdr J, Cajthaml T, Bárta J, Šantrůčková H, Baldrian P (2014) When the forest dies: the response of forest soil fungi to a bark beetle-induced tree dieback. ISME J 8:1920-1931

Thomas FM, Blank R, Hartmann G (2002) Abiotic and biotic factors and their interactions as causes of oak decline in Central Europe. For Pathol 32:277-307

Torres-Vila LM, Echave-Sanabria AC, Mendiola-Díaz FJ, Moral-García FJ (2019) Mapping oak shoot browning in SW Spain using online imagery as virtual prospecting tool. Ann For Sci 76:32

Winter MB, Ammer C, Baier R, Donato DC, Seibold S, Müller J (2015) Multi-taxon alpha diversity following bark beetle disturbance: evaluating multi-decade persistence of a diverse early-seral phase. For Ecol Manag 338:32-45

Yang LH, Gratton C (2014) Insects as drivers of ecosystem processes. Curr Opin Ins Sci 2:26-32

Publisher's note Springer Nature remains neutral with regard to jurisdictional claims in published maps and institutional affiliations. 